THURSDAY, DECEMBER 22, J88r

\section{ARCTIC SUCCESS AND DISASTER}

THIS has been a stirring Arctic week. First we have the publication of one of the most remarkable narratives of one of the most successful Arctic voyages ever made, to which we refer in detail on another page. On Tuesday an influential deputation waited on the Earl of Northbrook, to urge upon Government the necessity of sending out an expedition to succour Mr. Leigh Smith in the Eira. And, also, on the same day, the wires which about two years ago transmitted the welcome news of the safety of Nordenskjöld's expedition in the Vega, and the successful navigation of the North-east Passage, bore to Europe the sad news of disaster to the feannette. Sad though the news be, it is not nearly so bad as was to be feared, for we doubt if many besides Mr. Gordon Bennett had any faith in the survival of the expedition, and the search parties that were to be sent out next spring were generally looked on as forlorn hopes. From the news which" has been transmitted from Yakutsk to St. Petersburg, and thence to London and Paris, it is not quite easy to make out the details. The following extract is from the telegram of the St. Petersburg New York Herald correspondent to the Paris office of that paper; he quotes from a telegram to General Ignatieff, dated Irkutsk, December 19:--

"The Governor of Jakutsk writes that on September 14 three natives of Hagau Oulouss de Zigane, at Cape Barhay, I 40 versts north of Cape Bikoff, discovered a large boat, with eleven survivors from the shipwrecked steamer Jeannette, who had suffered greatly. The adjunct of the chief of the district was immediately changed to proceed with a doctor and medicines to succour the survivors at Jakutsk and to search for the rest of the shipwrecked crew. Five hundred roubles have been assigned to meet the most urgent expenses. The engineer, Melville, has sent three identical telegrams, one addressed to the London office of the Herald, one to the Secretary of the Navy at Washington, the third to the Minister of the United States at St. Petersburg. The poor fellows have lost everything. Engineer Melville says that the Jeannette was caught and crushed by the ice on June 23 , in latitude 77 and 157 east longitude. The survivors of the Jeannette left in three boats fifty miles from the mouth of the Lena. They lost sight of each other during a violent gale and dense fog. Boat No. 3, under command of Melville, having reached the eastern mouth of the Lena on September 29, was stopped by icebergs near to the hamlet of Idolaciro Idolatre on October 29. There also arrived at Bolonenga boat No. I, with the sailors Hindmann and Hoross, with the information that Lieut. de Long, Dr. Ambler, and a dozen other survivors had landed at the northern mouth of the Lena, where they are at present in a most distressing state, many having limbs frozen. An expedition was immediately sent from Bolonenga to make diligent search for the unfortunates in danger of death."

From this and from the Reuter's telegram it would seem that Boat No. I has not yet turned up. The spot where the disaster overtook the feannette is a short dis- tance east of the most easterly of the New Siberian Islands. The exact spots where the boats landed are not quite clear, and probably there has been some misspelling of names ; but it is evident that it is somewhere on the complicated delta of the Lena. It will be remembered that the Feannette, the old Pandora, was sent out two and a half years ago by $\mathrm{Mr}$. Gordon Bennett, for Arctic exploration by the Behring Straits route. It now appears that Mr. Bennett's instructions were that the ship should keep by the east side of Siberia, and embrace the first favourable opportunity of making for the Pole. These instructions her Commander, Capt. De Long, had evidently been doing his best to carry out. She was last seen in September, 1879, when she was steering north-east from Wrangel Land. Probably she has run round the north side of the Island, and attempting the north-west route been caught in the drift like the Tegetthoff, and finally crushed. The sufferings of the unfortunate explorers must excite universal pity, though all will rejoice that it has not come to the worst with them. The route they took was a perfectly new one, and it is possible they may have something new and important to tell us. The expedition was in some respects of the old-fashioned kind, rushing blindly into regions about which absolutely nothing was known; but this is how all knowledge has been purchased. Still, had something of the scientific method of Baron Nordenskjöld been adopted, the result might have been different. Further news of the shattered but so far saved expedition will be anxiously looked for; they will have an exciting and terrible story to tell, but we trust that their sufferings will prove not barren of results to science. If they have established the existence of a line of islands to the north of the New Siberian Islands, one more of the Arctic problems will have been solved.

In view of this disaster, no doubt it will be a relief to many to learn that Lond Northbrook's reply to the deputation from the Geographical Society was quite favourable and that probably a relief expedition will be sent out for the Eira. At the same time we believe a Government expedition, however much Mr. Leigh Smith deserves, such attention, was not necessary; and we doubt much if Mr. Leigh Smith's relatives were not rather surprised when it was suggested to them that they should petition for Government assistance. Now that the search expedition is virtually decided on we wish it every success, at the same time hoping that it will be strictly confined to its ostensible purpose. To Government Arctic explorations we are certainly favourable; but we trust that the next expedition sent out will be constituted and organized on as thorough a scientific method as that in the Vega; and that, as in the Vega, there will not only be a special scientific staff, but that the real commander of the expedition, subject to contingencies of navigation, will be a man with the scientific training and methods of Baron Nordenskjöld. In short, let the staff consist of men trained in the various departments of science, and not primed in haste for the occasion.

The unfortunate disaster to the Feannette will no more check Arctic exploration than many another greater disaster that has marked the progress of knowledge; it can only be hoped, while expressing our genuine sympathy with the sufferers, that Arctic explorers will learn from it all the lessons it ought to teach. 